\title{
MORPHOLOGY, STRATIGRAPHY, AND GENESIS OF SMALL DRUMLINS IN FRONT OF THE GLAGIER MÝRDALSJÖKULL, SOUTH ICELAND
}

\author{
By Johannes Krüger and Henrik Hфjmark Thomsen* \\ (Department of Geomorphology, Geographical Institute, University of Copenhagen, \\ Haraldsgade 68, DK-2100 Copenhagen Ø, Denmark)
}

\begin{abstract}
Investigations have been made of the geomorphology, internal structure, and till fabric of small drumlins in a drumlin field exposed in front of the retreating northern part of Mýrdalsjökull, Iceland. The drumlins either comprise irregular drumlin complexes or they show clearly the shape of typical drumlins with their highest points at the up-glacier ends of streamlined hills.

The core of each drumlin consists either of undisturbed glacio-fluvial deposits or glacio-dynamically deformed drift. The distribution of the first type often has a characteristic en échelon arrangement, similar to the interstream areas in the upper reaches of outwash fans. The second type forms a pattern with a predominant trend conforming to the glacier margin; this type is superimposed on overridden ice-margin push-moraine ridges. It is shown that the material in the drumlin cores is only slightly eroded by the glacier that formed the drumlins. The core is mantled by subglacial lodgement till about $0.1-1.5 \mathrm{~m}$ in thickness.

Seventeen fabric analyses of 25 clasts each were performed on material from within the till mantle. These analyses show a preferred long-axis orientation but indicate a considerable between-site variability ranging up to $45^{\circ}$ even between samples taken a few metres apart. The preferred clast orientation for samples taken along the drumlin crests only deviates $0-10^{\circ}$ from the regional ice-flow direction indicated by fluted moraines, whereas the deviation for samples from the flanks and the stoss-sides is up to $35^{\circ}$ However, the fabrics show a characteristic pattern relative to the shape of the drumlin; on their tops, the clast fabric parallels the ice-flow direction, whereas it tends to follow the contour direction on the flanks and stoss-sides.
It is concluded that the cores of the drumlins consist of pre-existing deposits, whereas the mantles are composed of subglacial till. Regarding the processes involved, the material contained in the core is mainly eroded by pro-glacial melt-water streams and not by ice. During the subsequent flow of ice across the area, the most prominent terrain elements have acted as subglacial obstacles, leading to localized till deposition and drumlin formation. Thus, the drumlins were formed mainly by subglacial deposition of till but the obstacles acted as an essential factor favouring their initiation.
\end{abstract}

RÉsumÉ. Morphologie, stratigraphie et origine de petits drumlins devant le front du glaciaire Mýrdalsjökull, Islande du Sud. On a poursuivi des recherches sur la géomorphologie, la structure interne et l'origine des dépôts de petits drumlins dans une zone faisant face à la partie nord, en recul, du Mýrdalsjökull, Islande. Les drumlins ou bien constituent des complexes irréguliers de drumlins, ou bien montrent clairement la forme de drumlins typiques, collines allongées dans le sens de l'écoulement avec des points hauts du côté regardant l'amont du glacier.

Le coeur de chaque drümlin consiste soit en des dépôts glaciofluviaux soit en amoncellements déformés par la dynamique glaciaire. La distribution du premier type a souvent un caractère "en échelon" semblable aux interfluves dans les zones supérieures d'éventails de drainage hydrologique. Le second type est distribué avec une tendance prédominante à se conformer au tracé du front glaciaire; ce type est surimposé aux rides de moraines de poussée qui surmontent le front glaciaire. On montre que le matériel trouvé dans le coeur des drumlins est seulement faiblement érodé par le glacier qui a constitué les drumlins. Le coeur est enveloppé dans moraine de cavités sous-glaciaires sur environ 0,1 à $1,5 \mathrm{~m}$ en épaisseur.

17 analyses cristallographiques de 25 échantillons chacunes ont été conduites sur du matériel provenant du manteau morainique. Ces analyses montrent une orientation préférentielle des grands-axes mais indiquée une variabilité considérable entre les sites allant jusqu'à $45^{\circ}$ même entre des échantillons prélevés à quelques mètres les uns des autres. Les orientations préférentielles dans les échantillons prélevés le long de la crète des drumlins

\section{INTRODUCTION}

During the past three decades there have been important advances in the study of drumlin formation in areas of Pleistocene glaciation in North America and Europe. A variety of streamlined features of different size, elongation, and internal structure are covered

*Present address: Geological Survey of Greenland, $\varphi$ ster Voldgade 10, DK-1350 Copenhagen K, Denmark. diffèrent seulement de $0^{\circ}$ à $10^{\circ}$ de la direction locale de l'écoulement glaciaire indiquée par les moraines flutées, alors que les déviations notées pour les exemplaires issus des flancs et de la base va jusqu'à $35^{\circ}$. Cependent la cristallographie montre un comportement particulier selon la forme du drumlin; sur leur sommet les orientations sont parallèles à la direction de l'écoulement de la glace, tandis qu'elles tendent à suivre les lignes de niveau sur les flancs et la base.

On conclut que le coeur des drumlins est formé de dépôts préexistants tandis que leur manteau est composé de dépòts sous-glaciaires. A l'égard du processus invoqué le matériel contenu dans le coeur est érodé surtout par les eaux de fonte proglaciaire mais non par la glace. Durant les écoulements ultérieurs de glace dans la zone des drumlins les principaux éléments du relief de terrain ont agi comme des obstacles sous-glaciaires, conduisant à localiser le dépôt de matériel morainique et la formation de drumlin. Donc les drumlins se sont formés surtout par dépôt sous-glaciaires de matériel morainique mais les obstacles jouent un rôle essentiel pour favoriser leur genèse.

Zusammenfassung. Morphologie, Stratigraphie und Genese kleiner Drumlins vor dem Gletscher Mŕrdalsö̈ull, Süd-Island. In einem Drumlinfeld vor dem zurückgehenden Nordteil des Mýrdalsjökull auf Island wurden Untersuchungen der Geomorphologie, der inneren Struktur und des Geschiebegefüges kleiner Drumlins angestellt. Die Drumlins bilden entweder unregelmässige Drumlinverbände oder sie zeigen klar die Form typischer Drumlins mit dem höchsten Punkt auf den gletscherzugewandten Enden von stromlinienförmigen Hügeln.

Der Kern jedes Drumlins besteht entweder aus ungestörten fluvioglazialen Ablagerungen oder aus gletscherdynamisch verformtem Geschiebe. Die Verteilung des ersten Typs hat oft die charakteristische Staffel-Anordnung, ähnlich den Zwischenstromgebieten in den oberen Bereichen der Sanderflächen. Der zweite Typ formt sich zu Mustern mit einer vorherrschenden Richtung in Übereinstimmung mit dem Gletscherrand; dieser Typ ist auf überfahrene Stauchmoränen am Gletscherrand aufgesetzt. Es wird gezeigt, dass das Material in den Drumlinkernen nur leich von dem Gletscher, der die Drumlins geformt hat, erodiert ist. Der Kern ist von subglazialen Geschiebes mit 0,1-1,5 m Dicke unmantelt.

17 Gefügeanalysen von jeweils 25 Proben wurden am Material aus dem Geschiebemantel durchgeführt; sie zeigen eine bevorzugte Orientierung der langen Achsen, weisen jedoch eine beträchtliche Variationsbreite zwischen den verschiedenen Probestellen auf, die bis zu $45^{\circ}$ zwischen Proben, die in wenigen Metern Entfernung voneinander entnommen wurden, reicht. Die bevorzugte Richtung für Proben aus den Scheiteln der Drumlins weicht um $0-10^{\circ}$ von der regionalen Richtung des Eisflusses, zu erkennen aus geriefter Moränen, ab, während die Abweichung für Proben aus den Flanken und den Stossfronten bis zu $35^{\circ}$ beträgt. Doch zeigt das Gefüge ein charakteristisches Muster in Bezug zur Drumlinform. Auf den Scheiteln läuf das Gefüge parallel zur Fliessrichtung des Eises, während es an den Flanken und Stossfronten der Richtung der Konturlinien zu folgen sucht.

Es wird geschlossen, dass die Kerne der Drumlins aus vorgefundenen Ablagerungen bestehen, während die Mäntel aus Grundmoräne gebildet sind. Was die beteiligten Prozesse betrifft, so wurde das Kernmaterial vor allem durch Schmelzwasserströme im Gletschervorfeld und nicht durch das Eis erodiert. Während der anschliessenen Überstromung des Gebietes durch das Eis wirkten die am meisten hervortretenden Geländeelemente als subglaziale Hindernisse, die zur lokalen Ablagerung von Geschiebe und zur Drumlinbildung führten. So entstanden die Drumlins vor allem durch subglaziale Geschicbeablagerung, doch spielten die Hindernisse eine wesentliche Rolle zur Auslösung des Bildungsprozesses.

by the term "drumlin" (Flint, [C1971]; Hi11, 1971; Glückert, 1973; Gravenor, 1974; Rose and Letzer, 1977; Menzies, 1979[b]; Whittecar and Mickelson, 1979; De Jong and others, 1982); but also reports on the spatial distribution of drumlins differ (Reed and others, 1962; Heidenreich, 1964; Vernon, 1966; Smalley and Unwin, 1968; Trenhaile, 1971; Hill, 1973; Rose and Letzer, 1977; Menzies, 1979[b]). Their great variety points to variations in the theory of drumlin formation and numerous conflicting hypotheses 


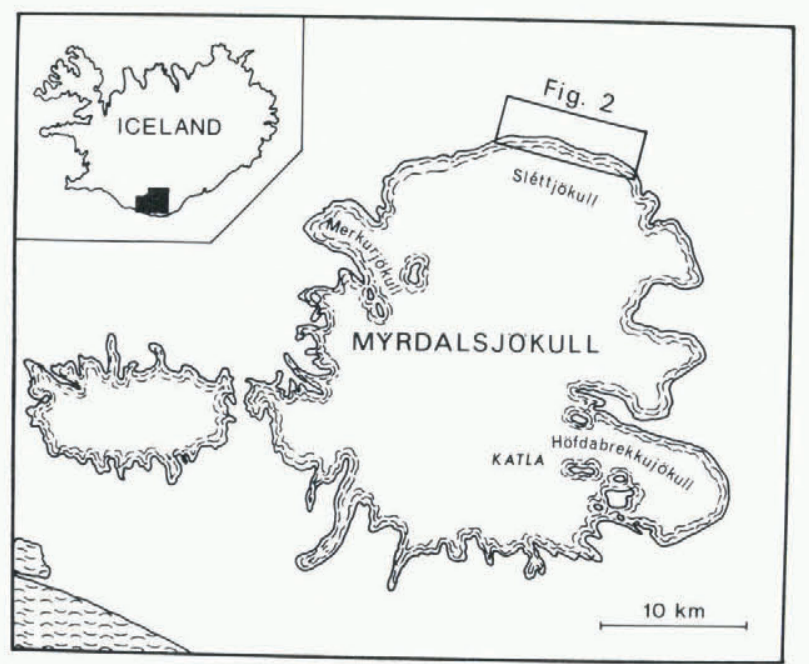

Fig. 1. Map showing the Myrdalsjokull ice cap and the location of the study area in front of the northerly extension of the ice cap known as slettjokult. In the study area the magnetic variation was measured as $22^{\circ} \mathrm{E}$ in 1979. In the following, the directional indications have been corrected for the magnetic variation.

have been put forward. In the literature, three main theories have been suggested for druml in formation: by glacial erosion of pre-existing deposits or knobs of bedrock, by basal deposition of drift from flowing ice, or by a combination of erosional and depositional processes (Kupsch, 1955; Jewtuchowicz, 1956; Charlesworth, 1957; Smalley and Unwin, 1968; Baranowski, 1969; Hi11, 1971; Shaw and Freschauf, 1973; Aario, 1977; Menzies, 1979[b]; De Jong and others, 1982).

There have been few attempts to apply the many theories of drumlin formation in Pleistocene areas to comparative investigations of form - process relationships in areas of recent glaciation (e.g.

Boulton, 1979). However, Menzies (1979[b]) suggested that, if the drumlins left by the Pleistocene ice sheets were to have their mode of formation understood, the most likely source of new information would be that obtained by interpreting present-day subglacial conditions.

In the following, the distribution, morphology, and stratigraphy of small drumlins from the northeastern forefield of Mýrdalsjökull, south Iceland, are described and their genesis discussed (Fig. 1).

\section{LOCATION OF STUDY AREA}

Mýrdalsjökull is a small, temperate ice cap situated about $150 \mathrm{~km}$ east-south-east of Reykjavik. The ice cap, which covers the volcanic Katla massif, has a surface area of $596 \mathrm{~km}^{2}$ (Björnsson, [1980]). The northern part of Mýrdalsjökull, known as Sléttjökull (Rist, 1967), has a continuous glacier terminus almost $21 \mathrm{~km}$ in length. The pro-glacial area has a gentle relief about $600 \mathrm{~m} \mathrm{a.5.1.} \mathrm{and} \mathrm{consists}$ of unlithified sediments of mainly glacial and glacio-
fluvial origin.

GEOMORPHOLOGY AND STRATIGRAPHY UF THE GLACIER FOREFIELD

The large-scale geomorphology of the glacier forefield is given in Figure 2. The forefield is bounded by an ice-marginal push moraine which extends $1200-$ $1500 \mathrm{~m}$ beyond the present-day glacier front, separating extensive areas of fluted or slightly drumlinized ground moraine from the outwash plain, known as Maelifell sandur. The marginal moraine was probably formed during a glacier advance at the end of the nineteenth century when many of the Icelandic glaciers were of greater extent. In 1906 the north-eastern margin of sléttjökull was situated only 50-140 m behind the most outlying ridges of the marginal moraine (Sapper, 1909). Since that time the glacier has apparently retreated continuously and with a sharp boundary between the flowing ice and the ice-free glacier forefield (Krüger and Humlum, 1981). The result of the frontal glacier retreat is the exposure of ground moraine which is much diversified by basins of lacustrine sediments, melt-water channels, and outwash fans.

The ground moraine is either gently undulating or almost flat with a relief rarely exceeding 3-4 m. It is associated with flutes, small drumlins, and annual moraine ridges formed by small-scale glacier advances during the winter (paper by J. Krüger in preparation). Furthermore, there are large-scale transverse features which are gently arcuate and conform with the marginal moraine system and the present glacier

Fig. 2. Geomorphological outline map of the slettiökult forefield. 1. Ice; 2. Marginat moraine ridges; 3. Medial moraine; 4. Fluted ground moraine; 5. Overridden push-moraine ridge; 6 . Small melt-water channel in ground moraine; 7. Large melt-water channel; 8. Erosion scarp; 9. Outwash plain with braided river channels; 10 . Basalt topography. Mapped on the basis of field observations and air photographs taken in 1979. The locations of the four selected drumlins $(A, B, C$, and $D)$ and the drumlin fields (Fig. $4 a$ and b) are shown.
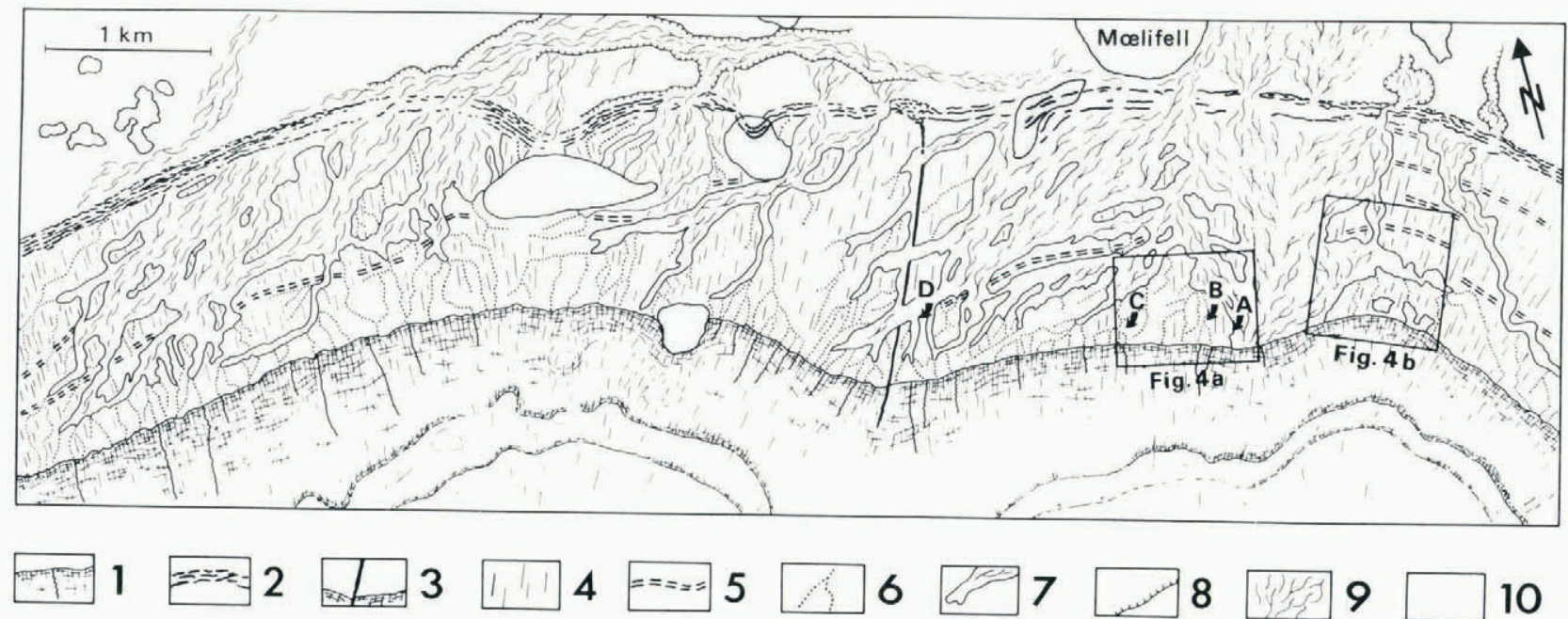
front. They appear as very smoothed ridges, 2-4 $\mathrm{m}$ high and 50-100 m wide, often with a fluted or drumlinized surface and a core of dislocated drift. These ridges are interpreted as overridden ice-marginal moraines. They were formed by an earlier ice advance and have survived the later ice movement across the area (Krüger and Humlum, 1981).

South of Maelifell, a complex system of outwash fans has formed by migrating braided streams concurrently with the glacier retreat. Close to the meltwater exit points, the sandur surface demonstrates coarse, gravel-dominated facies, representing proximal outwash sedimentation. Because of the disintegration of the original outwash fans by erosion of melt water, a branching network of channels and intervening bars, sharp-cut plateaux and terraces of varying age characterizes the morphology of the proximal outwash sediments. Furthermore, melting of buried ice has developed a distinct kettle topography on the surfaces of some of the plateaux.

A generalized picture of the stratigraphy of the glacier forefield south-west of Maelifell, showing the major lithostratigraphic divisions and the locations of structural deformation, is given in Figure 3 .

The lowest division is mainly a cross-bedded and parallel-bedded medium- to coarse-grained sand facies, indicating a palaeocurrent direction towards the north. The thickness of this undisturbed division exceeds $2-3 \mathrm{~m}$.

At site a, close to the present glacier front, the sand facies is overlain by lower till which has a yellow-grey colour. Sorted sediments embedded in the till consist of sub-horizontal lenses and schlieren of sand and gravel deposits. The observed maximum thickness of this till bed is $1 \mathrm{~m}$. On the basis of its sedimentological and structural components, the lower till is interpreted as lodgement till. During the stage of deposition, the ice flow was directed towards the north. The lower till passes laterally into a zone of structural deformation, indicating an ice push from the south (site b situated on the overridden marginal moraine ridge). Immediately in front of this zone there is a wedge of coarse gravel facies representing proximal outwash sedimentation (site $c$ ). The lateral contact of these deposits emphasizes that the ice-thrust ridge marks a former ice-marginal interface between contemporaneous, pro-glacial sedimenta-

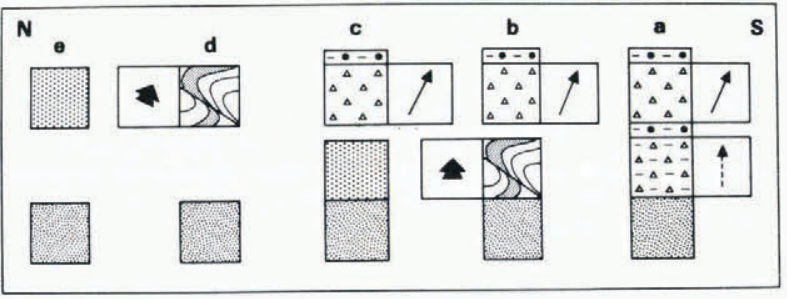

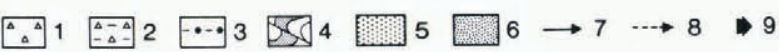

Fig. 3. Selected glacio-stratigraphic columns representing a simplified section through the glacier forefield south-west of Maelifell. The lithological units are not drawn to scale. 1. Upper till; 2. Lower till; 3. Clast pavement or layer of sand; 4. Glaciodynamic deformation; 5. Coarse gravel facies; 6 . Coarse-grained sand facies; 7. Ice-flow direction indicated by till fabric; 8. Ice-flow direction indicated by clast striae; 9 . Direction of glacial push. Location of the colwmns: $a$. In the drumlinized ground moraine between the overridden marginal moraine ridge and the glacier front; $b$. On the overridden moraine ridge; $c$. On the till plain about $900 \mathrm{~m}$ behind the furthermost push moraine but immediately in front of the overridden marginal moraine ridge; $d$. On the furthermost push-moraine ridge; $e$. On the outwash fan about $20 \mathrm{~m}$ in front of the furthermost moraine ridge. tion to the north of it and subglacial sedimentation of the lower till to the south of it.

At sites $a, b$, and $c$, the succession is capped by an upper till which is dark grey and compact. The thickness of this bed is $0.1-1.5 \mathrm{~m}$. Geomorphological and sedimentological components indicate an ice movement towards the north-north-east during deposition of the upper till. At site $d$, the upper till passes laterally into a zone of glacio-dynamic deformation, indicating an ice push from the south-south-west.

This zone coincides with the outermost marginal moraine ridge, representing the maximum forward position of the re-advancing ice cap.

The surface of the upper till (sites a, b, and c), and occasionally the interface between the lower and upper tills (site a), is characterized by a coarse layer of clasts $1-15 \mathrm{~cm}$ in size. This layer is interpreted as a residual which has escaped subglacial frictional deposition (Humlum, 1981). At present this surface layer is being deposited subaerially from the glacier sole concurrently with retreat of the glacier front.

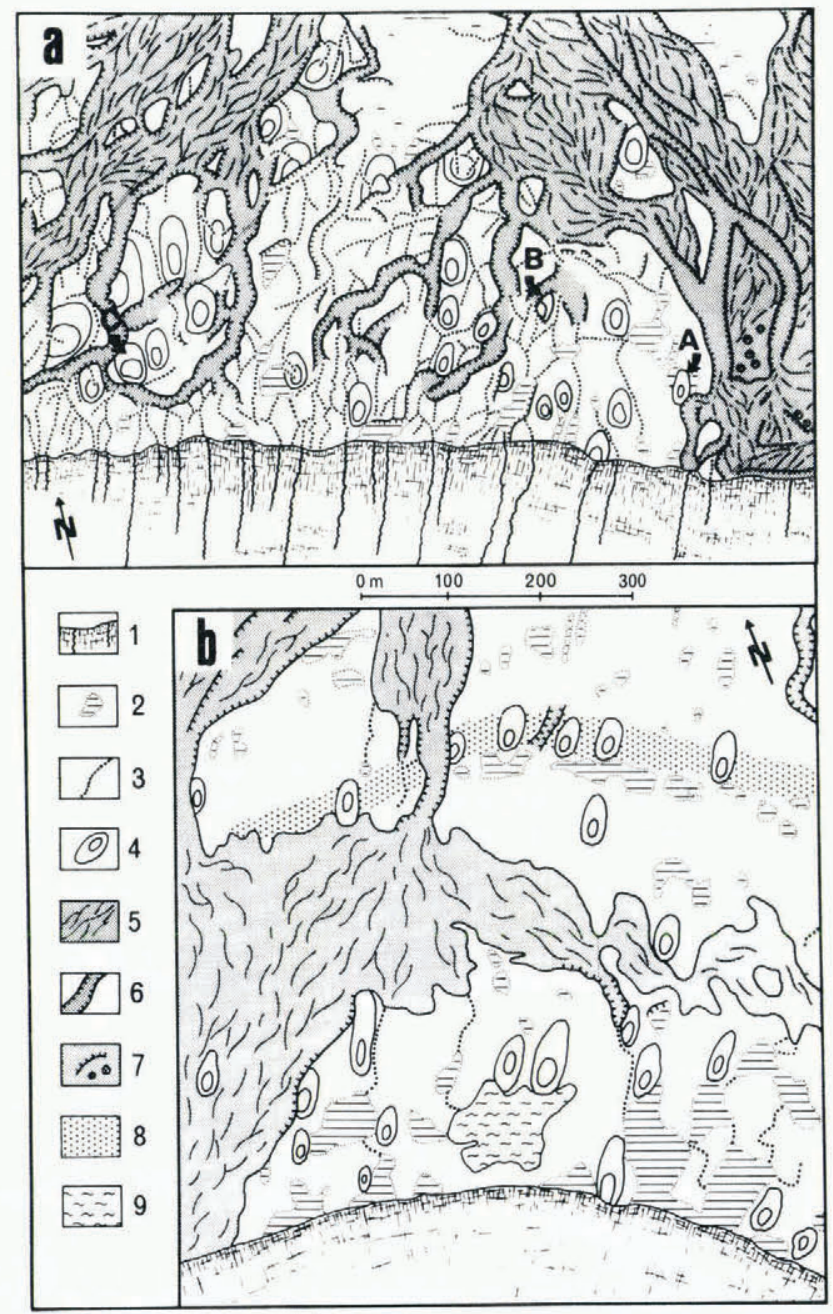

Fig. 4. Geomorphology of the drumlin field in two selected areas in the forefield of slettjokull; for locations see Figure 2. 1. Glacier margin with supraglacial melt-water streams; 2. Ground moraine with basins of glacio-fluvial and lacustrine sediments; 3. Small melt-water channel in ground moraine; 4. Drumlin; 5. Outwash plain with braided river channels; 6. Large melt-water channel; 7. Erosion scarp and kettles; 8. Overridden marginal moraine ridge; 9. Lake. The locations of the selected drumlins $(A, B$, and $C$ ) are also shown. Mapped on the basis of field observations and air photographs taken in 1979. 
Taken together, the lithostratigraphic divisions of the glacier forefield are interpreted as a response to a limited glacier advance, a following retreat, and a more extensive re-advance succeeded by the present retreat of Sléttjökull.

\section{GEOMORPHOLOGY OF THE DRUMLIN FIELD}

The detailed geomorphology of drumlin fields in two selected areas (see Fig. 2), representing different distributions of drumlins, is given in Figure 4. In both areas, moraine ridges in the shape of small low-relief drumlins are widely distributed in the glacier forefield and are furthermore currently emerging from beneath the retreating ice front. The drumlins are 20-80 m long, 1-3 m high, and their breadth averages between $15 \mathrm{~m}$ and $40 \mathrm{~m}$. Generally, they show a strong long-axis orientation in the regional icemovement direction and each has its summit in the proximal part of the hill. Thus, the shape of the hills with respect to the ice-flow direction fits well with the description of drumlins in the literature, but the present drumlins are extremely small. The westernmost of the selected areas (Fig. 4a) demonstrates a characteristic en échelon arrangement of many of the drumlins. Close to the glacier margin, however, melt water from numerous supraglacial streams is currently eroding small channels into the pro-glacial area in a direction predominantly normal to the ice front (Fig. 5). This process has affected

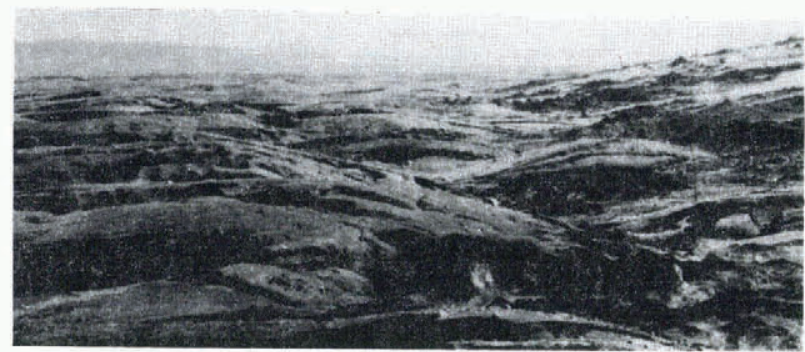

Fig. 5. View towards the east showing the drumlinized ground moraine between drumlin $C$ and the ice margin. The terrain is strongly dissected by numerous meltwater channels. (Photograph taken in 1979.)

many moraine ridges assumed to be drumlins to such an extent that it has been impossible to recognize their ground plan. Therefore, the map given in Figure $4 a$ only shows the best-preserved drumlins.

In the easternmost of the selected areas (Fig. $4 b)$, many of the present drumlins are arranged side by side with a predominant trend conforming with the glacier margin. Apparently, they are superimposed on the overridden marginal push moraines. Compared with the western of the selected areas, the easternmost is characterized by a low drumlin density, and the inter-drumlin areas are almost flat and much diversified by small lakes and basins of lacustrine sediments. Supraglacial melt-water streams are almost absent and therefore only a few melt-water channels are found in the ground moraine close to the glacier margin.

The presence of drumlins developed in two different situations makes the Sléttjökull forefield a particularly interesting one for an investigation of the processes of drumlin formation.

In the following, four selected drumlins ( $A, B$, $C$, and D) are described. Their locations are shown in Figures 2 and 4.

\section{DESCRIPTION OF LOCALITIES}

Drumlin A: a till-mantled drumlin containing an undisturbed core of lower till and sorted drift

This drumlin is located $100-140 \mathrm{~m}$ in front of the present ice margin. It was exposed in the early
1970 's as interpreted from air photographs and field observations. The drumlin is elongated in a southsouth-west to north-north-east direction and approximates a half pear in shape with the crest line closely paralleling the ice-flow direction, and the transverse axis is situated up-stream from the midpoint of the long axis (Fig. 6). The stoss end is steep and

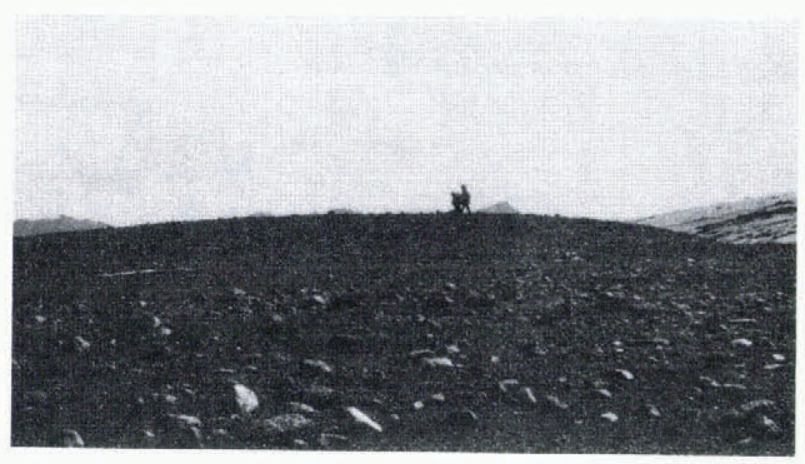

Fig. 6. The morphology of drumlin A clearly shows the shape of a typical drwnlin, indicating that its highest point is situated at the up-glacier end of the small elongated hill. Glacier flow is from right to left. Note the large number of clasts scattered on the ground moraine. View towards the east-south-east. (Photograph taken in 1982.)

blunt, while the lee end is more pointed and gentler in slope. Measured on the geomorphological field map, the drumlin is $38 \mathrm{~m}$ long, $22 \mathrm{~m}$ wide, and $1.5-2 \mathrm{~m}$ high (Fig. 7a).

The character of the drumlin surface corresponds to that of the gently undulating ground-moraine terrain between the drumlins. The surface is fluted and there are a great number of clasts ( $>10 \mathrm{~cm}$ long axis) with a smoothed, often bullet-nosed, up-glacier termination and an abruptly truncated down-glacier termination. Taken collectively, they suggest subglacial deposition by lodgement and indicate the last iceflow direction across the hill (Boulton, 1978; Krüger, 1979; Sharp, 1982).

The internal composition of drumlin $A$ is shown in Figures 8 and 9 . The faces being worked into a bank, which is located at the stoss end of the drumlin, are approximately at right-angles and tend to be transverse (sections $X-Y$ and $Z-V$ ) or parallel (section $Y-Z$ ) to the drumlin long axis. Furthermore, holes were dug along the centre line of the drumlin. Examination in this manner enabled the authors to distinguish between two till beds resting on three different facies of glacio-fluvial deposits.

In the lower zone of section $Z-V$, the right-hand part consists of ripple-laminated fine sand showing stoss-side preservation. This facies indicates that the suspended load contributed significantly to sedimentation. Apparently, the sedimentation was connected with pro-glacial ponding of melt water in what was formerly a subglacial depression. The palaeocurrent directions are towards the east and northeast. The left-hand part consists of a channel filled with essentially massive medium- to coarse-grained sand. The channel axis has a north-north-west trend. close to the right-hand bank, a wedge-shaped structure of sediment-flow deposits cuts the fine sand facies. This structure is interpreted as a collapse feature related to the channel formation.

The two sand facies pass upwards with an abrupt facies change into a coarse-gravel facies consisting of well-rounded to sub-angular clasts up to $30 \mathrm{~cm}$ in size. This facies can be traced laterally along the whole exposure and also occurs at the bottom of the three excavations (Fig. 9). The thickness of the boulder gravel varies from 20 to $30 \mathrm{~cm}$. The gravel 


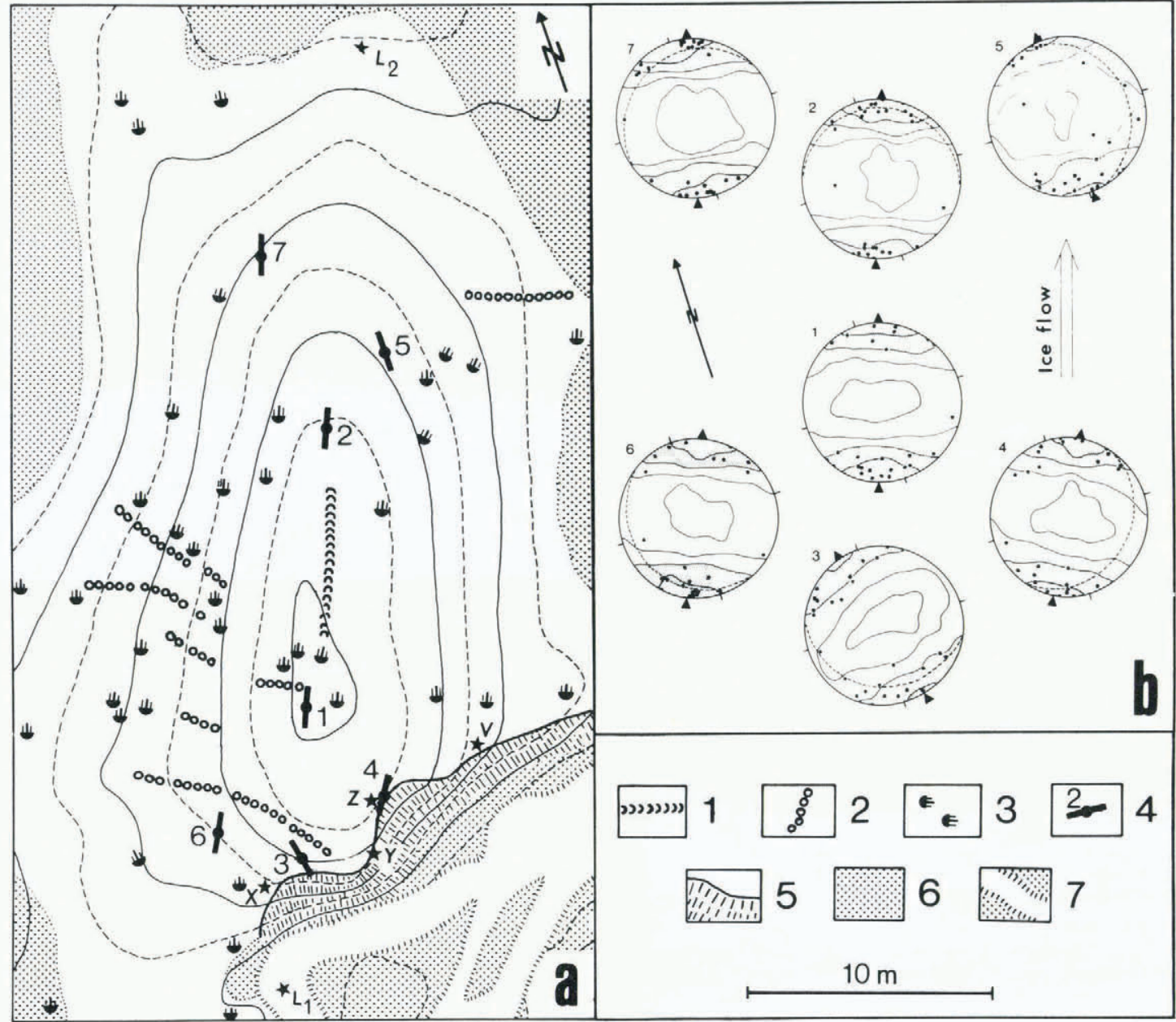

Fig. 7. a. Geomorphological map of drumlin A. Contours are at $0.25 \mathrm{~m}$ intervals. 1 . Fluted moraines; 2. Annual moraine; 3. Clast with stoss-and-lee form. Lee side to the right; 4. Clast fabric in the upper till; 5. Cutting with scree; 6. Basin of glaciofluvial or lacustrine deposits; ?. Melt-water stream. The locations of the sections $X-Y-Z-V$ (Fig. 8) and $L_{1}-L_{2}$ (Fig. 9) are shown. Glacier flow is from the south-south-west. Mapped in the field in 1982.

$b$. Projections (on the lower hemisphere of a Wulff net) of the three-dimensional orientation of clast a-axes for the upper till in drumlin A. The contouring procedure follows the method suggested by Kamb (1959). However, the area of the counter is modified in accordance with the gradual modification of the scale from the centre to the periphery of the Wulff net. The contour interval is three times the standard deviation from a random distribution. The dotted area visualizes the statistical significance of the apparent orientation peak which is shown by the black arrows. The dot - dash line indicates the sloping terrain surface. Nos 1-7 correspond to the sample sites shown in Fig. $7 a$.

surface rises $50-70 \mathrm{~cm}$ above the base of the druml in and slopes gently northward. This facies is interpreted as a bar deposit situated on the upper reach of a pre-existing outwash fan.

The above change of facies represents deposition under increasing flow strength, which is commonly associated with glacier advance. However, evidence of weathering and soil development on the bar deposits makes it reasonable to conclude that the bar had been exposed for a long time. It appears, then, that the increased flow velocity was connected with glacier retreat. It is suggested that the gravel facies migrated laterally concurrently with the extension of an outwash fan. The fan was formed in front of the glacier margin which retreated across a horizontal or low-angle normal slope. In this way, pro-glacial lake sediments and channel deposits were buried by coarse-grained bar deposits. This conclusion is supported east of drumlin A (see Fig. 2), where present-day development of fan-shaped wedges of glacio-fluvial sediments is taking place.

The top half of the section (Fig. 8) consists of two tills: the lower till, which has a yellow-grey colour, and the upper till, which is dark grey and compact.

The lower till is $40-50 \mathrm{~cm}$ thick in the centre of the hill but it lenses out rapidly in transverse directions. Sorted sediments included within the till consist partly of sub-horizontal lenses of sand and gravel, and partly of smudges of soil remnants. It seems reasonable that the lenses and smudges were detached from the substratum by dragging ( $c f$. Krüger, 1979). The bar surface underlying the lower till is striated in an approximately south to north direction. The smoothed and striated up-glacier termination of a clast (16 cm long) embedded in the lower till suggested an ice-flow direction towards the north-north-east. The lower till is therefore thought to have been deposited by a north-moving glacier. The lithostratigraphic columns shown in Figure 9 reveal that the lower till is not related to the drumlin surface.

There is evidence to indicate the nature of the interval between deposition of the lower and upper tills. A thin layer of sand or clasts has been found between the two tills in the three excavations (Fig. 9). It is suggested that the coarse layer of clasts 

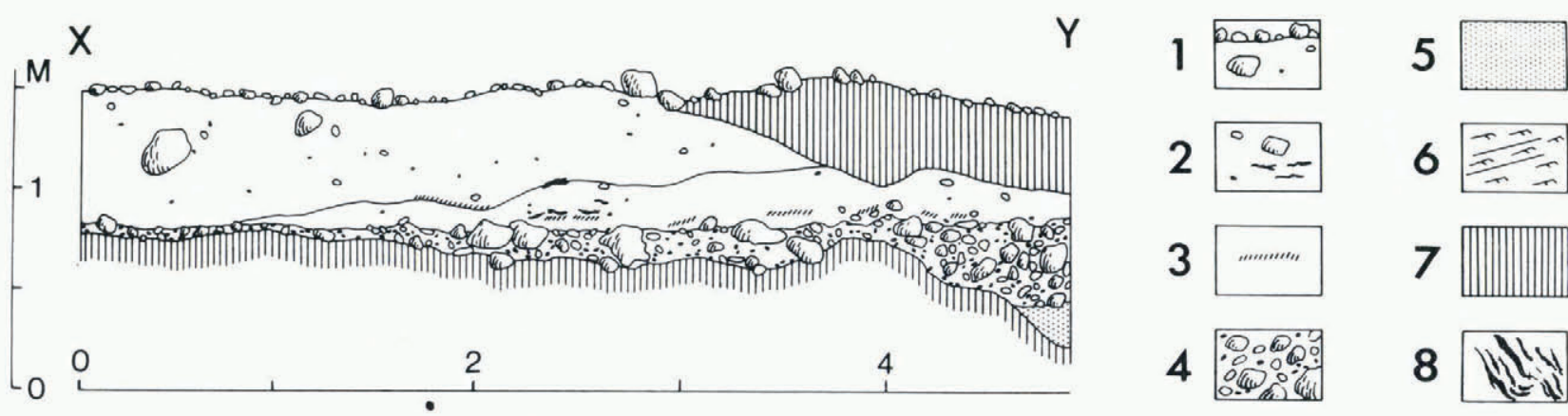

3

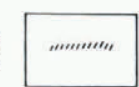

7
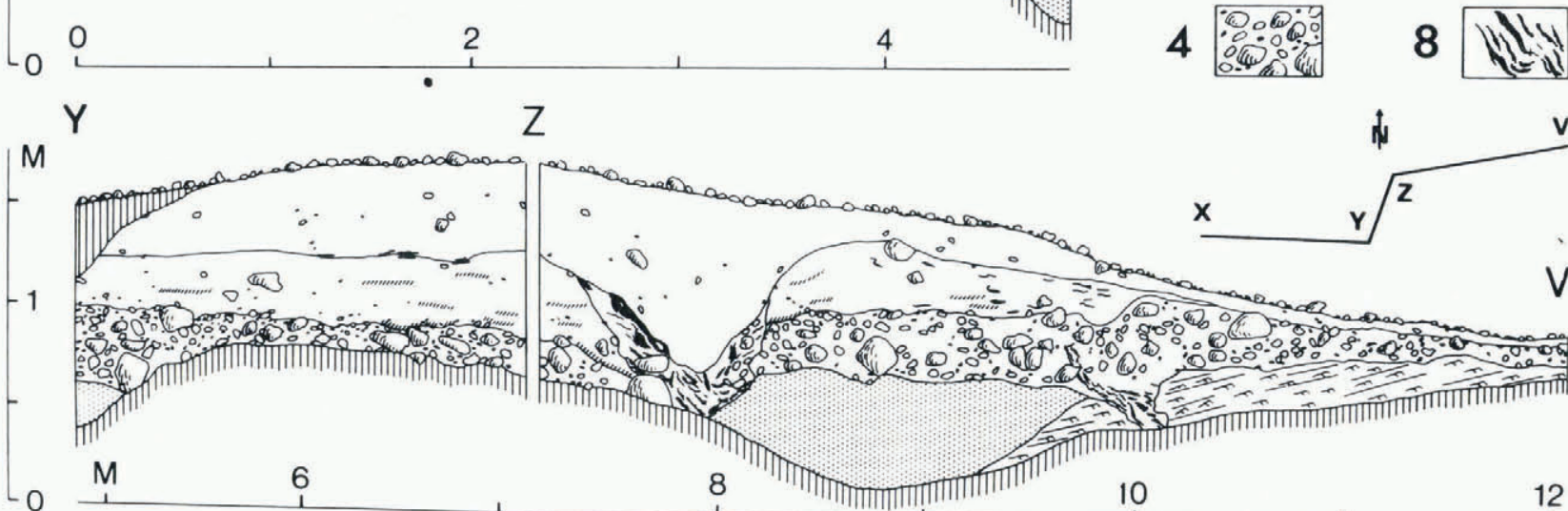

Z
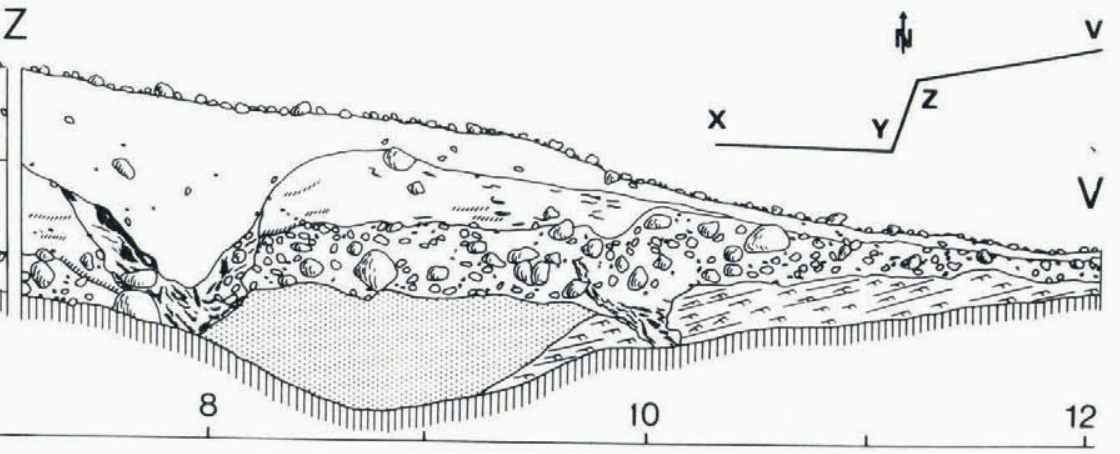

Fig. 8. Exposure in the stoss end of drumlin A (see Fig. 7a). 1. Upper till mantled by a coarse layer of clasts; 2. Lower till with schlieren and lenses of sand or gravel; 3. Layer with soil development or smudges of soil remnants; 4. Glacio-fluvial boulder gravel; 5. Massive medium- to coarse-grained sand; 6. Ripple-laminated fine sand; ?. Scree; 8. Sediment-flow deposits.

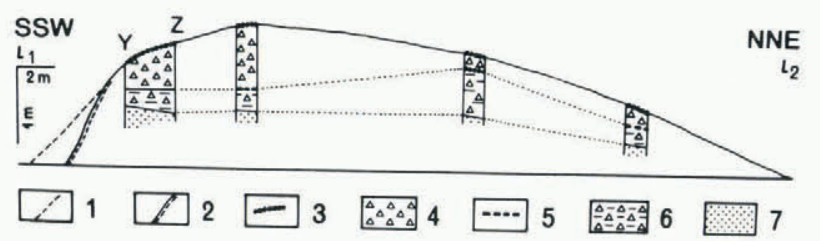

Fig. 9. Lithostratigraphic colums representing a longitudinal section through drumlin A (see Fig. 7a). 1. Initial stoss-side surface; 2. Present surface of scree; 3. Clast pavement; 4. Upper till; 5 . Layer of sand; 6. Lower till; 7. Coarse gravel facies.

indicates an ice-free period between the two glacial phases. Furthermore, in section $Z-V(F i g .8)$ a pocket-like structure ( $1 \mathrm{~m}$ wide and $0.8 \mathrm{~m}$ deep) cuts the lower till, the boulder-gravel facies, as well as the underlying sand facies. It is filled with sediment-flow deposits and the upper till. The long axis of this structure strikes south-south-east to northnorth-west, diverging approximately $40^{\circ}$ from the druml in trend. It is interpreted as a melt-water channel formed in exposed ground moraine during a frontal deglaciation of the area (cf. Krüger and Humlum, 1980). During the following ice advance across the area, the channel was filled with subglacial sediments. Similar channels have been studied in statu nascendi along the present-day ice margin (see Figs $4 a$ and 5). It is therefore concluded that the area was deglaciated by frontal retreat after deposition of the lower till.

The succession is capped by the upper till, forming a 40-80 cm thick surface layer on the top and on the stoss side of the drumlin, and thinning slightly to $10-20 \mathrm{~cm}$ on the flanks and on the lee side. It is seen that the characteristic shape of the drumlin is exclusively related to the upper till (Fig. 9).

In section $X-Y$ (Fig. 8$)$, two streamlined clasts, $21 \mathrm{~cm}$ and $34 \mathrm{~cm}$ long, were found in a characteristic position with a stoss-and-lee form relative to the ice-movement direction. Striae on the smoothed up- glacier termination of the boulders show a strong south-south-west to north-north-east orientation which coincides approximately with the long-axis orientation of the drumlin and the bullet-nosed clasts deeply embedded in the drumlin surface. The upper till is therefore interpreted as being a lodgement till deposited by a north-north-east-moving glacier.

Clast orientations have been determined at seven sites, all within the upper till range. The arrangement of the sampling sites is shown in Figure $7 a$. Samples of 25 clasts (blades and rods) were taken $10-15 \mathrm{~cm}$ below the terrain surface. Pebbles less than $0.6 \mathrm{~cm}$ long, or with a length : width ratio of less than $3: 2$, were excluded. Mean orientations were determined using the symmetry axis of the dotted areas in the diagrams (Fig. 7b).

The fabric diagrams indicate a distinct long-āis orientation. The mean orientations deviate $0-33^{\circ}$ from the ice-flow direction. Between-site variability is considerable, ranging up to $45^{\circ}$ even between samples a few metres apart. The mean orientation for samples taken along the crest of the drumlin deviates only by $0-2^{\circ}$ (sites 1 and 2) from the regional ice-flow direction, whereas the deviation for samples located at the flanks is up to $21^{\circ}$ (sites $4-7$ ). At site 3 , situated on the stoss side, most clasts are in a diagonal position relative to the ice-movement direction. Apart from sites 6 and 7 , the fabrics show a characteristic pattern relative to the shape of the drumlin; on the stoss side and eastern flank the preferred clast orientation tends to follow the contour direction, and on the crest the fabric strongly parallels the ice-flow direction. The fabrics show no preferred a-axis dip down-slope or any other evidence of disturbance by solifluction. The close relationship between fabrics and drumlin shape suggests that drumlin $A$ is mainly depositional in origin.

It seems justified to conclude that the stratigraphy and sedimentology of drumlin A implies that an interstream area of bar deposits covered by the lower till has acted as a subglacial obstacle leading to localized lodgement-till deposition and drumlin formation with the morphological axis parallel to the regional ice-flow direction. 


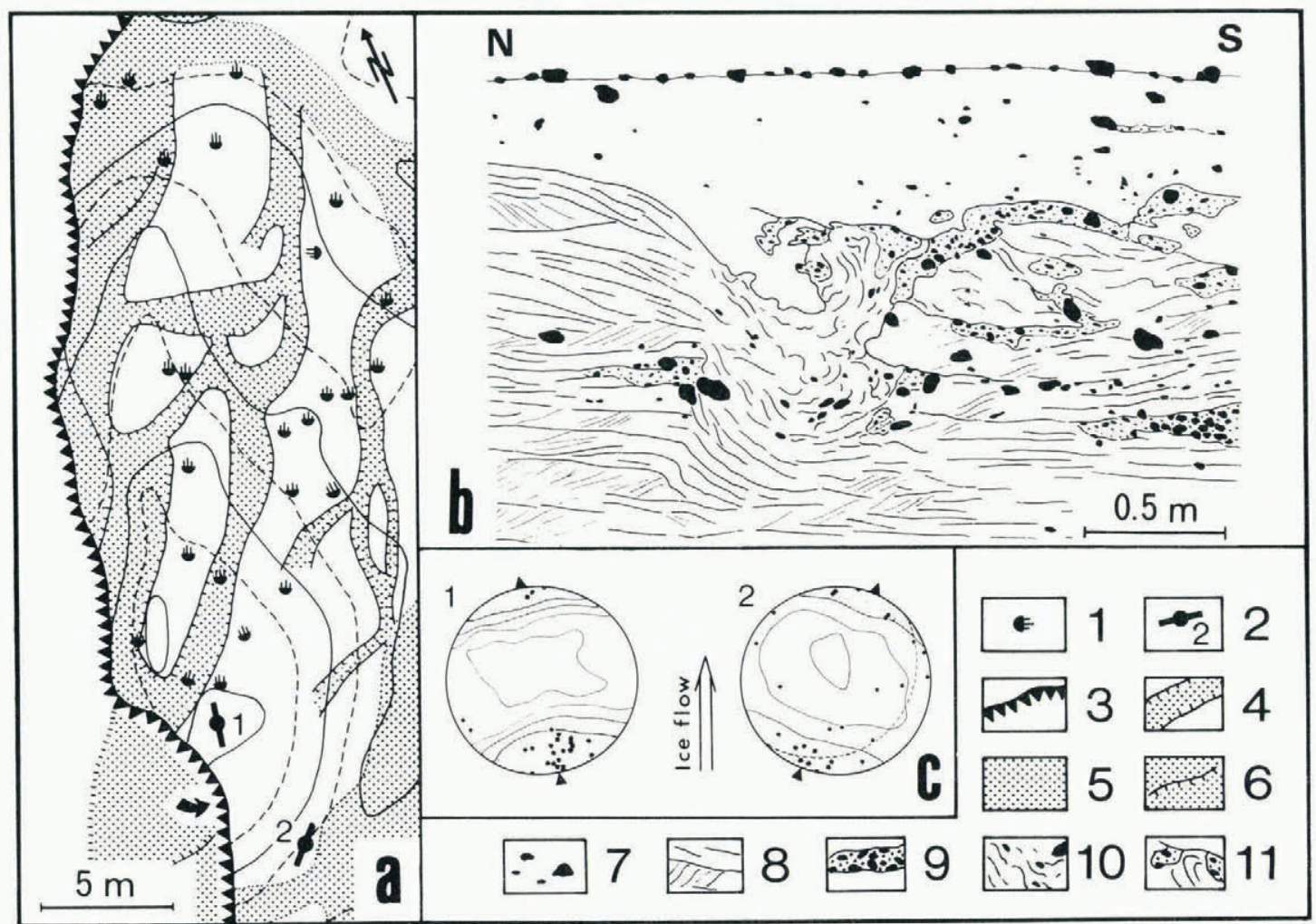

Fig. 10. a. Geomorphological map of drumlin B. Contours are at $0.25 \mathrm{~m}$ intervals. 1. Clast with stoss-and-lee form. Lee side to the right; 2. Clast fabric in the upper till; 3. Exposure; 4. Melt-water channel; 5. Terrace of glacio-fluvial deposits; 6 . Erosion scarp. The arrow indicates the location of the section shown in Figure 10b. Glacier flow is from the south-south-west. Mapped in the field in 1982. $b$. Collapse structure developed in glacio-fluvial deposits in the proximal end of drumlin B. 7 . Upper till; 8. Medium- to coarse-grained melt-water sand; 9. Glacio-fluvial gravel; 10. Collapsed melt-water deposits and sediment-flow deposits; 11. Glaciodynamically disturbed drift.

c. Fabric diagrams showing clast a-axis orientation in the upper till. For an explanation of the data presentation and contouring method, see the caption to Figure?.

Drumlin B: a till-mantled drumlin consisting predominantly of undisturbed sorted drift

Druml in B, which is located $170-200 \mathrm{~m}$ in front of the glacier, became exposed about 1970 (Fig. 4a).

It is $30 \mathrm{~m}$ long and with its long axis mainly southsouth-west to north-north-east (Fig. 10a). This direction accords with the regional ice flow. The drumlin is $1-1.5 \mathrm{~m}$ high with its highest point located in the up-glacier part. The surface is characterized by a network of small channels, obviously formed by meltwater erosion during the last glacier retreat across the hill.

The western flank of the drumlin is in the process of destruction by a violent melt-water stream, and a section, $35 \mathrm{~m}$ long, located close to the centre of the hill exposes the internal composition and structure in the long-axis direction of the drumlin. The main part of the exposure is of the drumlin core and consists of undisturbed sorted layers of medium- to coarse-grained sand, occasionally with layers of gravel and stones. Bedding planes are normally straight and parallel to sub-parallel. Special attention was focussed on a collapse structure, $1.5 \mathrm{~m}$ wide and $1 \mathrm{~m}$ deep, exposed in the proximal part of the section during the 1982 survey (Fig. 10b). It could easily be seen that no lateral compaction was involved; the underlying sand strata were unaffected by the deformation, while the surface of the glacio-fluvial deposits showed a depression, about $0.5 \mathrm{~m}$ deep. It was bounded by small-scale displacements and slump phenomena were developed in the glacio-fluvial deposits apparently under the influence of gravity. The conclusion can only be that a block of ice, $0.5 \mathrm{~m}$ thick and $0.5 \mathrm{~m}$ wide (measured in the face of the section), became buried by glacio-fluvial sediments. When it melted, a kettle was formed.

Being confined to the up-glacier part of the kettle, glacio-dynamic drag structures make the kettle interesting for an understanding of the process of drumlin formation. Apparently, the kettle acted as a subglacial depression when the glacier sole passed over the glacio-fluvial formation. South of this depression the internal frictional resistance to movement in the glacio-fluvial deposits was overcome by the shear force generated by movement of the glacier. Consequently, the top layers were pushed or sliced of $f$ and squeezed into the depression, accompanied by formation of thrust planes and drag folds. Measurements showed fold axes trending $113-293^{\circ}$ and indicating north-north-east-moving ice. In contrast to this, the down-glacier edge of the kettle did not show any influence by moving ice. Here, the top layer of the glacio-fluvial formation could be traced from the bottom of the kettle to its down-glacier edge, where a degree of dip approaching the initial sedimentary slope was quickly attained. Thus, the presence of the kettle structure makes it possible to conclude that subglacial erosion of the sand facies was confined to the stoss end of the druml in core.

The glacio-fluvial formation is overlain by the upper till. The contact is sharp and a transitional zone of re-worked sand is present only in the most proximal part of the drumlin. The till forms a thin surface layer $20-50 \mathrm{~cm}$ thick on the stoss side, and thinning to $5-15 \mathrm{~cm}$ at the top and on the lee side.

Clast orientation has been determined for two 


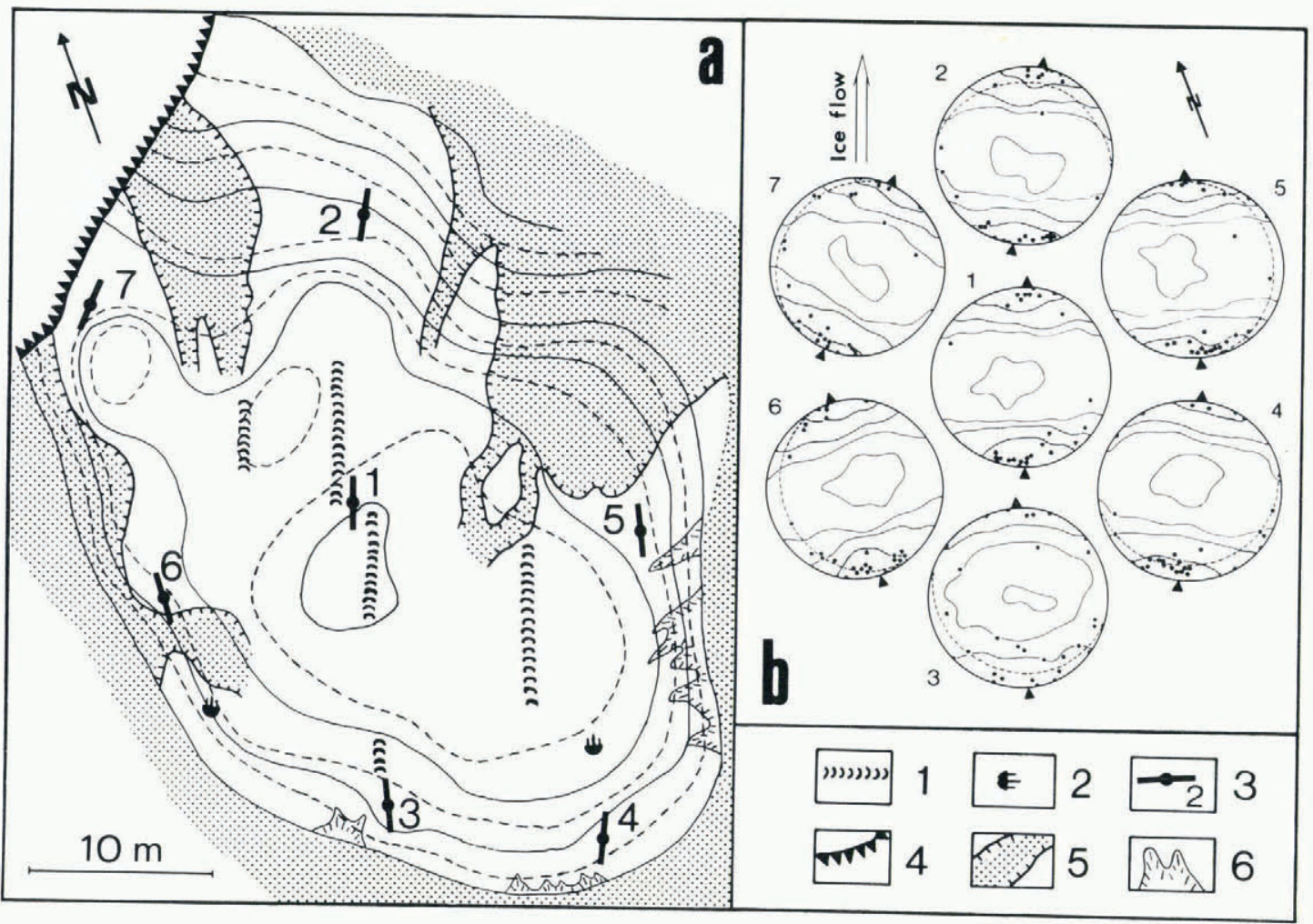

Fig. 11. a. Geomorphological map of drumlin C. Contours are at $0.25 \mathrm{~m}$ intervals. 1. Fluted moraine.

2. Clast with stoss-and-lee form. Lee side to the right; 3 . Clast fabric in the upper till; 4. Exposure; 5. Melt-water channel; 6. Gully. Glacier flow is from the south-south-west. Mapped in the field
in 1979 .

b. Fabric diagrams showing clast long-axis orientation in the upper till. For an explanation of the data presentation and contouring method, see the caption to Figure ?.

sites situated at the top and on the southern flank (Fig. 10a). The mean orientation for the sample taken from the top deviates only $6^{\circ}$ from the regional iceflow direction, whereas for the fabric at the flank the deviation is $28^{\circ}$ (Fig. 10c). Furthermore, it is seen that the two fabrics accord with the pattern found in drumlin $A$.

It is concluded that the streamlined shape of drumlin B is predominantly related to a pre-existing form, which has only been slightly modified by subglacial till sedimentation.

Drumlin C: a till-mantled drumlin complex containing an undisturbed core of sorted drift

This drumlin is located $75-125 \mathrm{~m}$ in front of the present ice margin (Fig. 4a). It was exposed in the early 1970's. The druml in is $50 \mathrm{~m}$ long, $35 \mathrm{~m}$ wide, and 1.5-2.5 $\mathrm{m}$ high (Fig. 11a). It is not a typical druml in but rather a drumlin complex such as described by Rose and Letzer (1977). The long axis of the ground plan trends north-north-west to southsouth-east, diverging $35^{\circ}$ from the regional icemovement direction.

The drumlin surface conforms to that of the surrounding ground moraine but, in places, melt water from the retreating ice margin has cut small channels, only $10-20 \mathrm{~cm}$ deep, into the druml in surface. Along the stoss side and eastern flank, where the terrain slope is relatively steep, the surface is dissected by small gullies apparently formed by rain water.

The internal composition of drumlin $C$ was stud ied in a section located at the distal end of the drumlin and in a number of excavations. The drumlin consists of a core of undisturbed glacio-fluvial deposits (medium- to coarse-grained sand), overlain by the upper till. The till forms a surface layer about $60-100 \mathrm{~cm}$ thick on the top, stoss side and flanks of the drumlin, thinning to $10-20 \mathrm{~cm}$ on the lee side.

Clast orientations have been determined at seven sites (Fig. 1la). The preferred orientation for samples taken along the crest of the drumlin deviates only $1-9^{\circ}$ (sites 1-3) from the regional ice-flow direction (Fig. 11b), whereas the deviation for samples from the flanks is up to $19^{\circ}$ (sites 4-7). It is significant that the fabric variation along the flanks shows a systematic pattern related to the shape of the hill and much similar to that of druml in $A$.

It is suggested that the atypical ground plan of druml in $C$ both in shape and orientation depends upon the shape of the glacio-fluvial interstream body forming the core of the drumlin. The final shape of the drumlin, however, was formed by the gradual accumulation of subglacial till as shown by the systematic variation demonstrated in till thickness and fabric. Drumlin D: a till-mantled drumlin containing a core
of dislocated drift

Druml in D is located approximately $400 \mathrm{~m}$ in front of the present ice margin (Fig. 2). It was exposed in the early 1960's. Since that time, the druml in has been considerably affected by northward-flowing meltwater streams. Not only the eastern flank and distal end but also the central part of the hill are cut by abandoned melt-water channels, while the western flank is in the process of destruction. This made it impossible to trace the ground plan of the small hill. However, an exposure $50 \mathrm{~m}$ long and $4 \mathrm{~m}$ high with its face more or less parallel to the regional ice-flow direction shows the surface profile of a typical drumlin. The northern part of this exposure shows three divisions (Fig. 12a).

The lowest division is exposed irregularly at the base of the section. It is a medium- to coarse-grained 
NNE

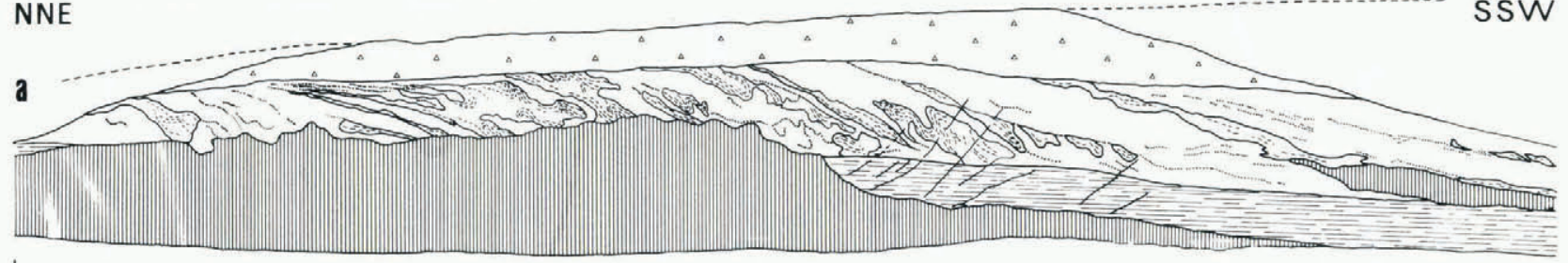

$\underline{E}$

1

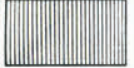

2

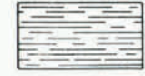

3

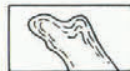

4

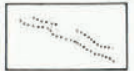

5

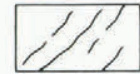

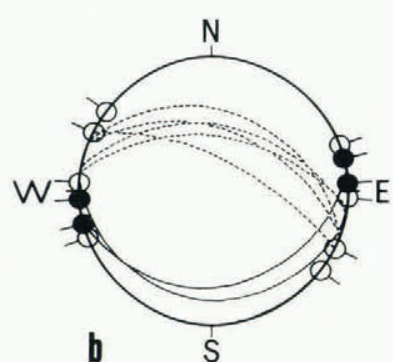

b

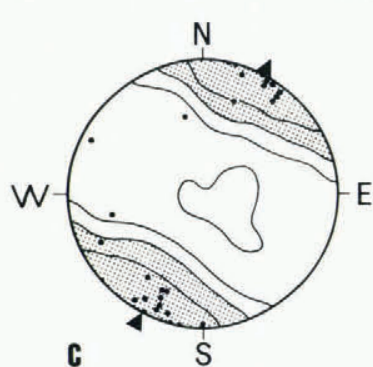

c

S

Fig. 12. a. Exposure in the northern (distal) end of drumlin D. The right-and left-hand parts of the section are cut by abandoned melt-water channels. 1. Scree; 2. Medium- to coarse-grained melt-water sand; 3. Dislocated melt-water deposits; 4. Thrust planes in till; 5. Tension cracks. 6. Upper till. Glacier flow is from right to left.

b. Trend of thrust planes (solid lines) and tension cracks (dashed lines), as well as measured (open circles) and constructed (solid circles) fold axes (on the lower hemisphere of a Wulff net).

c. Point and contour diagram showing the long-axis orientation of 25 blades and rods from the upper till. For an explanation of the data presentation and contouring method, see the caption to Figure ?.

sand facies, indicating a palaeocurrent direction towards the north. The absence of large-scale deformation structures suggests an undisturbed position for these sediments.

The main part of the exposure shows strongly deformed till and sorted drift. The structures range from simple thrusts to complicated overfolds. The maximum thickness of this division is $1.3 \mathrm{~m}$. The dislocated inclusions and schlieren of sorted drift consist of sand which corresponds to the mechanical composition of the subjacent bed of glacio-fluvial deposits. The inclusions are interpreted as fragments of the underlying formation.

Thrust planes and fold axes display a consistent directional pattern. Measurements show fold axes trending approximately east-west and thrust planes dipping towards the south (Fig. 12b). Structural deformation of the drumlin's internal material, probably indicative of the effects of overriding ice, have been demonstrated by Minel1 (1973). However, the zone of tectonic-like structures seen in the section under discussion coincides with the form of the overridden marginal moraine ridge that trends towards the eastnorth-east (see Fig. 2). Therefore, it may be concluded that in the present case the dislocated part has resulted from marginal deformation and by ice coming from the south.

The dislocated part is discordantly overlain by the upper till (0.5-1 m thick) which forms the outer mantle of the hill, except where the till cover has been removed by glacio-fluvial erosion (see the right- and left-hand parts of the section shown in Figure 12a). The maximum thickness of the till occurs in the proximal part of the hill.

Clast orientations have been determined for the lee side of the drumlin and about $20 \mathrm{~cm}$ below the terrain surface within the upper till. The fabric diagram indicates a distinct south-south-west to north-north-east long-axis orientation (Fig. 12C). This fabric accords with the regional ice-flow direction.

In the central part of the section, one set of closely spaced cracks cuts the glacio-dynamic structures and the underlying sand facies (Fig. 12a). The cracks dip at $30-60^{\circ}$ towards the north-north-east and are slightly concave upwards in the section. They show a consistent structural trend of approximately east-south-east to west-north-west (Fig. 12b). These cracks are interpreted as tension features formed by ice moving towards the north-north-east across the marginal moraine ridge.

The exposure suggests two phases in the formation of drumlin D: first, the formation of the marginal push-moraine ridge and, subsequently, drumlinization of the most prominent parts of the moraine ridge by the gradual accumulation of till from the base of an overriding glacier.

\section{DISCUSSION}

Investigations of small drumlins in front of the northern margin of Mȳrdalsjökull have revealed streamlined hills of both pre-existing and newly deposited sediments. Two main types of composition are present. First, drumlins which contain an undisturbed, or slightly disturbed, core of pro-glacial melt-water deposits covered by a layer of upper till about 0.1-1 m in thickness (drumlins $A, B$, and $C$ ); occasionally, a lower till is found in the upper part of the core (drumlin A). Secondly, drumlins which have cores of strongly deformed and sorted drift covered by an upper till about $0.5-1 \mathrm{~m}$ in thickness (drumlin D).

A relationship between the composition and spatial arrangement of the drumlins has been demonstrated. The first type often shows a characteristic en échelon arrangement like elongated interstream areas in the present glacier forefield. The second type mainly forms individual drumlins arranged side by side with a predominant trend conforming to the glacier margin. This type is superimposed on overridden ice-marginal push-moraine ridges. In both cases, studies of the cores show that the orientations of directional parameters cannot be related to the last ice that flowed across the area.

It is seen that the present drumlins cannot be regarded as a set of points across a flat landscape but some account needs to be taken of the pre-existing topography.

The above drumlin characteristics suggest that prior to drumlin formation the two main types of core were morphological elements located in a glacier fore- 
field. They were marginal push-moraine hills or interstream areas of melt-water deposits between incised, erosional melt-water channels in the upper reaches of outwash fans, or they were fragments of ground moraine of lower till which had been considerably affected by pro-glacial melt-water erosion. Areas of the present glacier forefield demonstrate similar scenery under development.

None of the drumlins investigated supports the hypothesis that drumlins are formed mainly by subglacial erosion. Instead, both the surface elements and the concentric arrangement of the upper till over the cores suggest that the drumlins were formed mainly by deposition of the upper till. It should also be noted that the streamlined druml in surface, as seen in druml in $A$, is moulded in upper till and not in the core which retains an irregular surface.

Banding and partings similar to those described by Hill (1971) have not been observed within the upper till. The till within the drumlins appears to be very similar to that in the inter-druml in areas. Therefore, as a formative factor, texture may have little or no significance.

The analyses of till fabric from the four selected drumlins indicate that the upper till fabrics have preferred orientations within $\pm 35^{\circ}$ of the iceflow direction. This fabric variability differs significantly from that in the ground moraine between the drumlins where the fabrics have preferred orientations within $\pm 12^{\circ}$ of the regional ice-flow direction (Krüger and Thomsen, 1981). However, these fabrics show a characteristic pattern relative to the shape of the drumlin: on the top, the fabric parallels the ice-flow direction, whereas it tends to follow the contour direction on the flanks. No evidence of modification by solifluction subsequent to drumlin formation has been found in the fabric characteristics nor in the field. A similar relationship between fabric and drumlin shape has been presented by De Jong and others (1982) from Pleistocene areas.

There seem to be different processes by which fabrics might be related to drumlin shape: (1) by the influence of the drumlin relief on the local flow pattern of the basal ice; (2) by differential movement of the till beneath the glacier (Boulton, 1979); (3) by ice flow with a helicoidal motion (Shaw and Freschauf, 1973; Aario, 1977).

In the first case, the ice flow is increasingly deflected around the obstruction. In the proximal part of the drumlin the flow pattern may produce preferred clast orientations, which are directed slightly outwards, and in the distal part slightly inwards with respect to the drumlin axis. This implies that the till was deposited on a bulging glacier bed with considerable variability in dip and slope direction. Small drumlins emerging from beneath the retreating ice front demonstrate such an intimate adjustment of the debris-band foliation in basal ice to the drumlin shape.

In the second case, Boulton (1979) has demonstrated that beneath a moving glacier irregularities at the ice - till interface may produce a lateral component of flow in al ready deposited till. Thus, differential movement of the till will occur along smooth flow lines mainly following the shape of the glacier bed. If this process is widespread, it seems likely that the fabrics describe mean directions of movement of the till mass rather than basal ice-flow directions. This explanation seems to be supported by the fact that fabrics may diverge from the orientation of fluted moraines and bullet-nosed clasts (see Figs $7 a$ and 11a).

In the third case, Shaw and Freschauf (1973) have suggested that ice may flow with a helicoidal motion as it passes over the irregular bed, the resultant direction of flow being parallel to the direction of the main ice movement. This complex motion will result in erosion of the subglacial material where the ice flow is vertically directed downwards and depo- sition of material where ice flow is upwards (the glacial kinematic fluting theory). This model predicts a "herring-bone" till-fabric pattern. However, the helicoidal ice motion will result in redistribution of debris in the basal ice. Debris-charged ice will move towards separation points and clean ice will replace debris-charged ice in areas around points of attachment. There is no evidence of the redistribution of debris resulting from a helicoidal flow pattern within the active ice mass of Slettjökull.

The close relationship between fabric and drumlin shape favours the hypothesis that the drumlins considered here are mainly depositional in origin. If they were formed by erosion of the upper till, the fabric characteristics within the drumlins would be similar to those in the ground-moraine areas between the drumlins. Consequently, subglacial till deposition on an irregular glacier bed may produce significant fabric variability in contrast to a smoother glacier bed, which may lead to fabrics strongly parallel to the ice-flow direction. It should be noted that this relationship may result in misinterpretation of fabric analyses performed on Pleistocene till beds, because the palaeogeomorphology of overridden till beds is still generally unknown.

Thus, investigations of these small drumlins suggest that pre-existing terrain elements have acted as obstacles leading to localized till deposition and the formation of drumlins with their morphological axes parallel to the regional ice-flow direction. According to Boulton ([C1974]), pressure differentials are produced across obstacles in the path of the moving ice mass. Therefore, the location of the maximum till thickness in the proximal parts of the drumlins may be explained by the increased accumulation of till at the glacier base, in a zone of higher pressure in the proximal parts of obstacles (Boulton, [C 1974$], 1979)$.

It is a pre-condition of the present theory that an already existing core exists to allow accretion to proceed. For those drumlins that have no apparent core, other mechanisms to allow druml in initiation have been proposed in the literature, such as the dilatancy theory (Smalley and Unwin, 1968; Trenhaile, 1975) and the frost-heave theory (Baranowski, 1969). Menzies (1979[a]) discussed the mechanics of drumlin formation with particular reference to the change in pore-water content of the till. He postulated that, if till is flowing beneath an ice mass, small local areas of low pressure could act at locations where the till could develop into a proto-drumlin, acting as an obstruction around which more till would accrete. In front of Sléttjökull, the pre-existing topography, the internal composition of the drumlins, and the nature of the sub-druml in materials all indicate the validity of the mechanisms of pore-water and water-film removal. However, in the present case an already existing body of drift is a pre-requisite to drum? in initiation.

There is some evidence to indicate the subglacial pressure conditions which have led to druml in formation. During glaciation of the druml in field, the glacier bed became irregular as a result of proglacial melt-water erosion, and it consisted of apparently deformable porous sand and gravel. In such cases, subglacial water rapidly drains into cavities or may be discharged into permeable beds. The dissipation of pore water will increase the shear strength of sands and gravels at the interface thus allowing it to withstand higher imposed basal ice stresses. It is possible that this factor may explain the absence of large-scale deformation structures within the drumlin cores. Furthermore, a relatively high effective normal pressure is produced through the rapid loss of water from the glacio-fluvial deposits, and the effective normal pressure will then be equal to the pressure of the overlying ice (Boulton, [ $\left.{ }^{C} 1974\right]$ ).

During the maximum extension of Sléttjökull in historical times (about 1900), the thickness of ice 
covering the present drumlin field was $100-150 \mathrm{~m}$, as interpreted from air photographs and field observations (Krüger and Humlum, 1981). It should be noted that drumlins are absent from the terminal $500 \mathrm{~m}$ of the glacier forefield where the maximum thickness of ice was less than $100 \mathrm{~m}$. It is therefore reasonable to conclude that, under the above conditions, drumlins may be formed beneath ice thicknesses greater than $100 \mathrm{~m}$, corresponding to a subglacial pressure exceeding 8 bars. This view is supported by the fact that drumlins are not moulded in the lower till, the extent of which seems to be confined to the area behind the overridden marginal push moraines which are located $500-700 \mathrm{~m}$ in front of the present ice margin (see Fig. 2).

In comparison with the descriptions of drumlins in the literature, the present drumlins are extremely small. This can be explained as having resulted from variation in different glacier factors such as content of debris in basal ice and duration of glaciation of the drumlin field. It seems that both the content of materials and the space of time available for drumlin formation have been extremely restricted (Huml um, 1981; Krüger and Humlum, 1981).

The above-mentioned glacier factors have also affected the druml in shapes, which range from streamlined hills to more irregular druml in complexes. It is believed that pre-existing sediment bodies, elongated in the ice-flow direction, mainly led to perfect druml in forms. In contrast to this, minimal till deposition prevented oblique bodies from being completely masked by the till mantle and moulded in the ice-movement direction. By this means, the last type of sediment body gave rise to the more irregular drumlins.

During the present-day retreat of the glacier, the extensive ground moraine and the numerous exposed drumlins are in the process of destruction by melt-water erosion. Furthermore, a branching network of channels, sharp-cut plateaux, and terraces characterizes the morphology of the proximal parts of outwash fans formed concurrently with glacier retreat.

Given the present glacier forefield, it is possible to predict from the above model for druml in formation how drumlins might evolve under a future advance of Sléttjökull across the forefield; prominent interstream areas in the upper reaches of the outwash fans and remnants of ground moraine between incised melt-water channels will lead to the formation of new drumlins, while pre-existing drumlins will be enlarged. In such cases, it is meaningless to relate morphometric analysis statements of randomness or non-randomness of druml in distribution to the characteristics of moving ice as has been frequently proposed in the literature (Reed and others, 1962; Trenhaile, 1971).

\section{CONCLUSIONS}

The internal composition and till fabrics of small drumlins in front of the northern margin of Mýrdalsjökull, Iceland, suggest that the cores of the drumlins consist of pre-existing deposits, while the mantle is composed of subglacial till. As regards the processes involved, the material contained in the cores is mainly eroded not by ice but by pro-glacial melt-water streams. During the subsequent flow of ice across the area, the most prominent terrain elements have acted as subglacial obstacles, leading to localized till deposition and druml in formation. Thus, it is concluded that the drumlins were formed mainly by the subglacial deposition of till but obstacles acted as essential factors favouring the initiation of drumlins. Although this mode of formation, beginning with a core, may be one initiating mechanism for drumlin development, it by no means accounts for drumlins without such cores, and therefore explains only a part of the overall problem concerning the origin of drumlins.

\section{ACKNOWLEDGEMENTS}

For financial support we wish to thank the Danish Natural Science Research Council and the Carlsberg Foundation. 0. Humlum, Department of Geomorphology, University of Copenhagen, took part in the field work, and discussions of observations and hypotheses. L. Pedersen and E. Lund, as well as students of the Geomorphological Department, A. Engraf, G. Hyde, and N.G. Mortensen, assisted in the field. K. Winther kindly improved the English of the text. To all these individuals, we extend our sincere thanks. Furthermore, we are grateful to the Icelandic National Research Council for allowing us to work at the margin of Mȳrdalsjökull.

\section{REFERENCES}

Aario, R. 1977. Classification and terminology of morainic landforms in Finland. Boreas, Vol. 6, No. 2 , p. 87-100.

Baranowski, S. 1969. Some remarks on the origin of drumlins. Geographia Polonica, No. 17, p. 197-208.

Björnsson, H. [1980.] The surface area of glaciers in Iceland. jökull, Ar 28, 1978, p. 31.

Boulton, G.S. [C 1974.$]$ Processes and patterns of glacial erosion. (In Coates, D.R., ed. Glacial geomorphology. Binghamton, State University of New York, p. 41-87.)

Boulton, G.S. 1978. Boulder shapes and grain size distribution of debris as indicators of transport paths through a glacier and till genesis. Sedimentology, Vol. 25, No. 6, p. 773-99.

Boulton, G.S. 1979. Processes of glacier erosion on different substrata. Journal of Glaciology, Vol. 23, No. 89 , p. $15-38$.

Charlesworth, J.K. 1957. The Quaternary era, with special reference to its glaciation. London, Edward Arnold. 2 vols.

De Jong, M.G.G., and others. 1982. Sedimentology and geomorphology of drumlins in western Allgäu, south Germany, by M.G.G. De Jong, M. Rappol, and J. Rupke. Boreas, Vol. 11, No. 1, p. 37-45.

Flint, R.F. [C 1971.$]$ Glacial and Quaternary geology. New York, John Wiley and Sons, Inc.

Glückert, G. 1973. Two large druml in fields in central Finland. Fennia, 120.

Gravenor, C.P. 1974. The Yarmouth druml in field, Nova Scotia, Canada. Joumal of Glaciology, Vol. 13, No. 67, p. $45-54$.

Heidenreich, C. 1964. Some observations on the shape of drumlins. Canadian Geographer, Vol. 8, No. 2, p. 101-07.

Hill, A.R. 1971. The internal composition and structure of drumlins in north Down and south Antrim, Northern Ireland. Geografiska Annaler, Vol. 53A, No. 1, p. 14-31.

Hill, A.R. 1973. The distribution of drumlins in County Down, Ireland. Annals of the Association of American Geographers, Vol. 63, No. 2, p. 226-40.

Humlum, 0. 1981. Observations on debris in the basal transport zone of Mýrdalsjökul1, Iceland. Annals of Glaciology, Vol. 2, p. 71-77.

Jewtuchowicz, S. 1956. Structure des drumlins aux environs de Zbojno. Acta Geographica Universitatis Lodziensis, No. 7.

Kamb, W.B. 1959. Ice petrofabric observations from Blue Glacier, Washington, in relation to theory and experiment. Journal of Geophysical Research, Vol. 64, No. 11, p. 1891-909.

Krüger, J. 1979. Structures and textures in till indicating subglacial deposition. Boreas, Vol. 8, No. 3 , p. 323-40.

Krüger, J., and Humlum, 0. 1980. Deformations - og erosionsstrukturer $i$ bundmoraenelandskabet ved Mȳrdalsjökul 1, Island. Dansk Geologisk Forening. Arsskrift for 1979, p. 31-39. 
Krüger, J., and Humlum, 0. 1981. The proglacial area of Mýrdalsjökull with particular reference to S1ëttjökull and Höfdabrekkujökul l: general report on the Danish geomorphological expedition to Iceland, 1977. Folia Geographica Danica, Tom. 15, No. 1.

Krüger, J., and Thomsen, H.H. 1981. Till fabric i et recent bundmoraenelandskab, Island. Dansk Geologisk Forening. Arsskrift for 1980, p. 19-28.

Kupsch, W.0. 1955. Drumlins with jointed boulders near Dollard, Saskatchewan, Canada. Bulletin of the Geological Society of America, Vol. 66, No. 3, p. 32737.

Menzies, J. 1979[a]. The mechanics of druml in formation with particular reference to the change in pore-water content of the till. Journal of Glaciology, Vol. 22, №. 87, p. 373-84.

Menzies, J. 1979[b]. A review of the literature on the formation and location of drumlins. EarthScience Reviews, Vol. 14, No. 4, p. 315-59.

Minel1, H. 1973. An investigation of drumlins in the Narvik area of Norway. Bulletin of the Geological Institutions of the University of Uppsala, New Series, Vol. 5, p. 133-38.

Reed, B., and others. 1962. Some aspects of drumlin geometry, by B. Reed, C.J. Galvin, Jr, and J.P. Miller. American Joumal of Science, Vol. 260, No. 3 , p. 200-10.

Rist, S. 1967. The thickness of the ice cover of Mýrdals jökull, southern Iceland. Jökuzl, Ar 17, p. 237-42.
Rose, J., and Letzer, J.M. 1977. Superimposed drumlins. Journal of Glaciology, Vol. 18, No. 80, p. $471-80$.

Sapper, K. 1909. Bemerkungen über einig südisländische Gletscher. Zeitschrift für Gletscherkunde, Bd. 3, Ht. 4, p. 297-305.

Sharp, M. 1982. Modification of clasts in lodgement tills by glacial erosion. Journal of Glaciology, Vol. 28 , No. 100, p. 475-81.

Shaw, J., and Freschauf, R.C. 1973. A kinematic discussion of the formation of glacial flutings. Canadian Geographer, Vol. 17, No. 1, p. 19-35.

Smalley, I.J., and Unwin, D.J. 1968. The formation and shape of drumlins and their distribution and orientation in drumlin fields. Journal of Glaciology, Vol. 7, No. 51, p. 377-90.

Trenhaile, A.S. 1971. Drumlins: their distribution, orientation, and morphology. Canadian Geographer, Vol. 15, [No.] 2, p. 113-26.

Trenhaile, A.S. 1975. The morphology of a drumlin field. Annals of the Association of American Geographers, Vol. 65, No. 2, p. 297-312.

Vernon, P. 1966. Drumlins and Pleistocene ice flow over the Ards Peninsula/Strangford Lough area, County Down, Ireland. Journal of Glaciology, Vol. 6, No. 45, p. 401-09.

Whittecar, G.R., and Mickelson, D.M. 1979. Composition, internal structures, and an hypothesis of formation for drumlins, Waukesha County, Wisconsin, U.S.A. Journal of Glaciology, Vol. 22, No. 87 , p. 357-71. 